\title{
COMPARISON OF SOME SOIL QUALITY INDICATORS OF FOREST SOILS UNDER TWO DIFFERENT TREE SPECIES
}

\author{
SHAYMAA ALI FATTAH* and MOHAMMED ALI FAYYADH** \\ *Dept. of Medical Laboratory Technology, Technical Institute of Amedi, Duhok Polytechnic \\ University, Kurdistan Region-Iraq \\ **Dept. of Soil and Water Science, College of Agricultural Engineering Sciences, University of \\ Duhok, Kurdistan Region-Iraq
}

(Received: August 5, 2019; Accepted for Publication: October 7, 2019)

\begin{abstract}
The study area was located at Duhok governorate, Kurdistan region, North of Iraq. Two study locations were selected under pine and oak forest cover. Five pedons were dug at each location and thirty three soil samples were collected air dried, grinded and sieved through (2) $\mathrm{mm}$ sieve to be used for physical and chemical analysis. pH values were indicate to slightly alkaline (7.39-8.10) and this is due to the presence of cations in increasing amounts and these soils are derived from calcareous parent material. EC values of all soil samples indicated to non-saline soils and attributed to desalinization process because affected by leaching process $\left(0.20-0.42 \mathrm{dS} . \mathrm{m}^{-1}\right)$. All exchangeable cations were concentrated at the surface and subsurface horizons ( $A$ and $B$ horizons) and lower concentration in deep horizons ( $C$ horizon) $\left(\mathrm{Ca}^{+2}=5.8-16.6, \mathrm{Mg}^{+2}=1.2-9.4, \mathrm{Na}^{+}=0.2-0.8, \mathrm{~K}^{+}=0.48-2.49 \mathrm{Cmol}_{.} \mathrm{kg}^{-1}\right)$, additionally at Sarki location $($ Oak forest) were relatively high values comparing with Zawita location (Pine forest) $\left(\mathrm{Ca}^{+2}=8.8-18.8, \mathrm{Mg}^{+2}=3.0\right.$ 10.0, $\left.\mathrm{Na}^{+}=0.13-0.87, \mathrm{~K}^{+}=0.76-2.68 \mathrm{Cmol}_{\mathrm{c} . \mathrm{kg}^{-1}}\right)$. CEC values at Zawita location under Pine forest cover

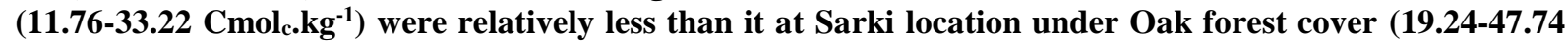
Cmol.. $\left.\mathrm{kg}^{-1}\right)$. Vertical distribution of calcium carbonates $\left(28.4-380.6{\mathrm{~g} . \mathrm{kg}^{-1}}^{-1}\right)$ in all study pedons under both forest covers indicated to increase total carbonate content towards downward of pedon from upper horizon to the lower horizons and this is belong to increasing rainfall effect and weathering of parent rocks. Generally, organic matter content in study pedons at both study locations under pine and oak forest covers was directly decreased towards depth of soil pedon $\left(8.82-101.04 \mathrm{~g}^{\circ} \mathrm{kg}^{-1}\right)$. Depending on the particles size distribution of study soils under pine trees indicated to the studying soils were clay, clay loam, and loam texture. Conversely, soil texture under oak trees was clay. Can be concluded study soil were calcareous, Clayey, alkaline, none saline, low organic matter and CEC with depth.
\end{abstract}

KEYWORDS: Forest soil, Organic matter, Depth, Cations, Soil texture, Oak trees, Pine trees https://doi.org/10.26682/ajuod.2019.22.2.14

\section{INTRODUCTION}

$\mathbf{F}$ orest soils, are the soils formed when affected by forest vegetation, in general they are characterized by $\mathrm{O}$ horizon which is an important litter layer, trees of deep roots, recycling of nutrients and organic matter including wide range of soil organisms and even wood, as the vegetation of forest varies largely, so do forest soils vary, they are deep, shallow, clayey, sandy, arid, wet, warm or frigid (Boyle, 2005). Individual mineral particles of sand, silt, and clay, may be aggregated into larger particles known as soil peds (Nelofer Jamil et al., 2016). The finer soil particles help to conserve water and nutrients in addition to binding soil particles together as structural aggregates, whereas the coarse particles serve as the soil skeleton, to make the soil permeable and well aerated.
Highest percentage of clay and lower percentage of sand under mixed vegetation and pure teak was due to deforestation and afforestation activities. The clay migration process was more (eluviation and illuviation) under pure plantation of teak than in mixed plantation and natural forests (Prasad et al., 1985). Soil texture is one of the most important properties of soil, which controlling water and nutrients retention, the exchange and uptake of oxygen. It is the leading characteristics of the soil that influences other properties and processes in the soil (Am-Euras, 2016).

Forest ecosystem gains their nutrients mostly from litter decomposition, and from any other organic matter at the surface of the soil. Soil organic matter includes exchange positions which enable the soil adsorption capacity to hold 
nutrients and preventing the nutrients from being leached below the root zone. Similarly organic matter in the soil comes from all biological living and nonliving sources; it is strongly indicate the health of soil because it affects different properties and functions of the soil. The source of energy for microorganisms in soil is the organic matter; also it is a store of nutrients. Stability of soil structure, $\mathrm{pH}$ buffering capacity, and water holding capacity are improved by soil organic matter (O’Neill et al., 2005). Furthermore Šnajdr et al., (2008) emphasized litter decomposition is of the major processes important for the temperate forest soils evolution and formation which evolve organic horizons and organic-mineral horizons with high humic materials contents. The particles of organic and inorganic colloidal are presents in most soils, as clay percent and organic matter increase; the CEC value also increases (Robert et al., 2009). Conversely, the specific surface area of colloids is very high, thus it gives the soil great ability to hold cations and release those into the soil, these colloidal materials are very important; because they are reinforce the nutrient status and the capacity of forest soil to hold water (Unanaonwi, 2013). Under forest tree cover cation exchange capacity is increase, because of increasing in organic matter in forest soils; also the CEC of humus is much higher than CEC of clay (Sharma and Yogender, 2004). On the other hand Marlow and Peart (2014) showed that the CEC of the oak forest soil much higher than the CEC of pine forest soils. Moreover Negash and Kagnew, (2013) revealed that the main indicator for the nutrient status and $\mathrm{pH}$ of the soil is the CEC. Additionally Jiang et al., (2012) explained Soil organic matter strongly affects the CEC of the soil and supply the soil by bulk exchange sites.

Dissolving of carbonates cause alteration in the soil properties through the exudates of roots which are cations and carbonic acid that forms from the $\mathrm{CO}_{2}$ evolving from respiration in the soil solution, $\mathrm{Ca}\left(\mathrm{HCO}_{3}\right)^{2}$ as a result is formed, which help in soluble and exchangeable cations restoration in the soil, in turn exchangeable sodium percentage decrease and enhance soil structure, and as a result soil hydraulic improve, this improvement in soil properties highlights the role of the carbonate in the soil, which is chemically inert (Pal et al., 2012). Pinus brutia is considered one of the most necessary forest ecosystem in the Mediterranean sea climate is adapt with different climatic conditions, and it participate in the ecological balance in the region which it grow in forest soils vary from agricultural soils in their effect by vegetation cover and organic layer presence consisting from dead remnants fall from trees, therefore the developme4nt of the soil under forest influence which is differ from shrubs and grasses influence, also parent material has an essential role in forest soils than agricultural soils (Adel Rukia et al., 2014)

This study aimed to investigate some physical and chemical properties under two different forest covers, and follow the pathway of some soil properties towards downward soil horizons of study pedons.

\section{METHODS AND MATERIALS \\ 2.1. Study Area and soil sampling}

The study area was located at Duhok governorate, Kurdistan region, North of Iraq. Two locations were selected at Zawita (N 36 ${ }^{\circ} 4^{\prime}$ $02^{\prime \prime}$, E $\left.43^{\circ} 08^{\prime} 48^{\prime \prime}\right)$ and Sarki (N 36 $58^{\prime} 47^{\prime \prime}$, E $43^{\circ} 12^{\prime} 08^{\prime \prime}$ ) (Fig. 1), depending on the forest trees species, accordingly pine (Pinus brutia Ten.), and oak (Quercus aegilops L.) forests were selected in both study locations respectively. Five pedons were dug at each location. Study pedons were morphologically described according to soil survey staff (2006), Thirty three soil samples were collected air dried, grinded and sieved through (2) $\mathrm{mm}$ sieve to be used for physical and chemical analysis. 


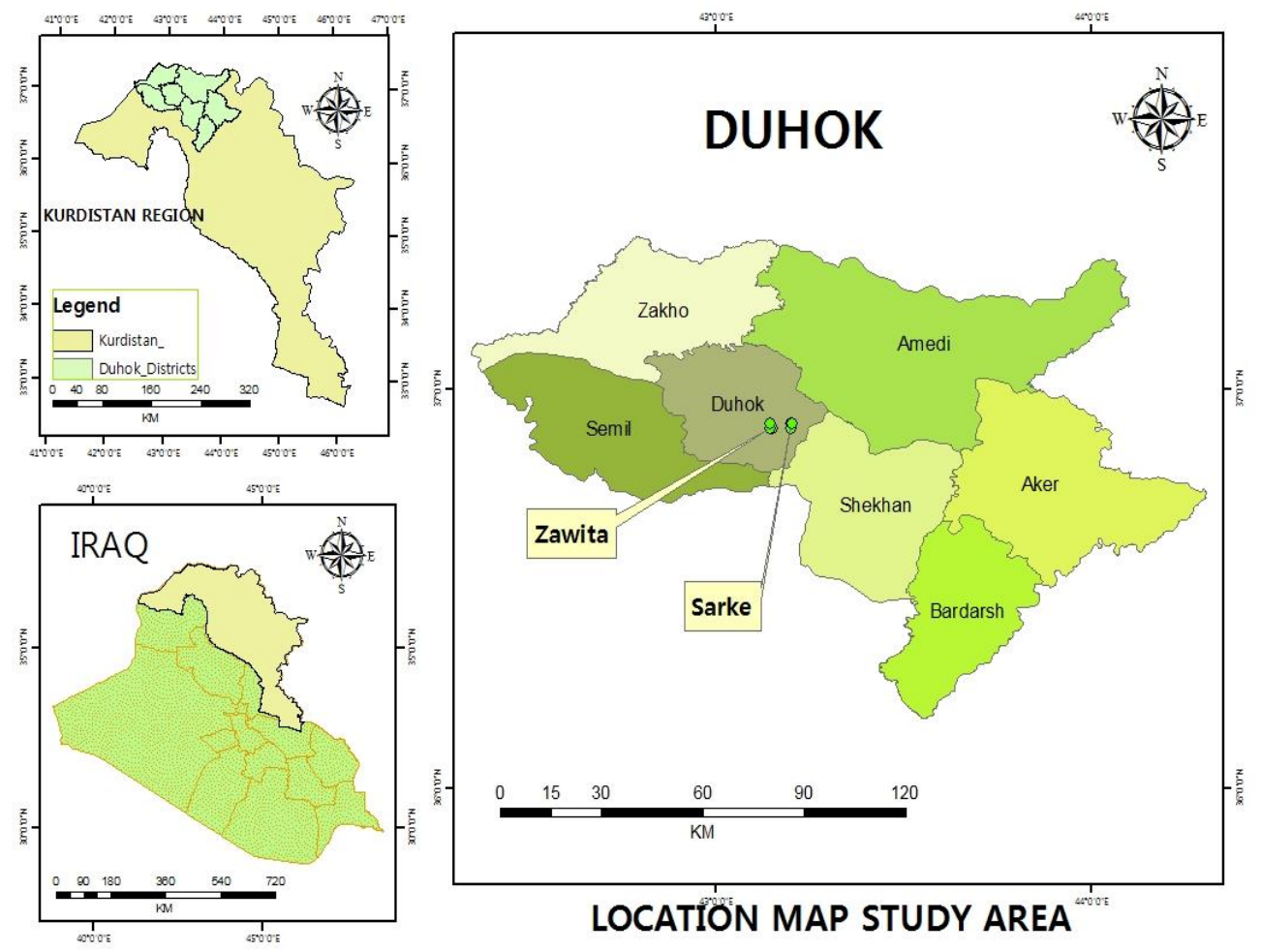

Fig. (1): Map of the Study Area

\subsection{Laboratory analysis}

Particles size distribution determined by hydrometer method as described by Klute (1986). Soil pH and EC were measured in soil suspension (1:2) (soil: water) with using $\mathrm{pH}$ meter, and EC-meter according to Rowell (1996). Total carbonates measured by reaction with using calcimeter device (Loeppert and Saurez, 1996). Exchangeable calcium, magnesium, sodium, and potassium were determined by procedure adopted by Page et al., (1982), furthermore soluble calcium and magnesium measured depending on Rowell (1996), whilst soluble potassium and sodium were measured as described by Hesse (1972). Cation exchange capacity was measured by flame photometer as used by Polemio and Roads (1977). Organic matter was determined by wet combustion method as described by Walkely and Black (1965). Soluble carbonate and bicarbonate estimated by titration with sulfuric acid $(0.01 \mathrm{~N})$ with using phenolphthalein and methyl orange indicators respectively, whereas soluble chlorides determined by titration with silver nitrate and using potassium chromate indicator (Estefan, et al. 2013). Study results were analyzed according to stipe wise multiple linear regression and correlation coefficient.

\section{RESULTS AND DISCUSSION}

\subsection{Soil Reaction (pH)}

The $\mathrm{pH}$ values at Zawita location under pine trees are ranged between (7.46-7.83), whereas at Sarki under oak trees are ranged between (7.39 8.10) (Table, 1). In spite of presumably $\mathrm{pH}$ values of forest soils were tends to be acidic but in both locations were indicate to slightly alkaline and this is due to the high buffering capacity of these soils as most cations in these soils are derived from calcareous parent material (limestone). The results explained that in (A) horizon in pedons $(1,4,5,7$, and 8$)$ the $\mathrm{pH}$ value was higher than it in subsurface horizons, the reason for that is the accumulation of cations in these horizons and the organic matter may be not completely decomposed to produce organic acids that decrease soil $\mathrm{pH}$ or may contribute the high amounts of fallen leaves which are contain in their structure the large amounts of cations that are released to the soil after the decomposition and the main reason is the amount of organic acids produced from organic matter decomposition is not sufficient to 
overcome the high buffering capacity of alkaline calcareous soils. In surface horizons, in pedons $(2,3,6,9,10)$ have $\mathrm{pH}$ values lower than it in subsurface horizons; this is due to the leaching process that leads to the accumulation of cations in subsurface horizons as a result of high rainfall amounts at the studied locations. On the other hand there are not significant differences in $\mathrm{pH}$ values between two study locations under pine and oak trees.

\subsection{Electrical Conductivity (EC)}

Electrical Conductivity values of the studied soils under pine trees cover are ranged between (0.21- 0.42) dS.m ${ }^{-1}$, while the EC value in soils under oak trees cover ranged between $(0.20$ 0.29) dS.m ${ }^{-1}$ (Table, 2) these EC values of all studied soil samples indicated to non-saline soils and attributed to desalinization process because affected by relatively high amounts of rainfall and increase the rate of leaching process in the studied pedons and in turn reducing the concentration of saline ion these results agree with Yahia, (1982) that found the EC value ranged between (0.18-0.47) $\mathrm{dS} . \mathrm{m}^{-1}$ at Zawita location. These low values of $\mathrm{EC}$ are due to the limestone parent material of the soil which contains calcium carbonate in its structure and its solubility in the water is low, and generally calcareous soils are not saline as denoted by Mahjoory (1975). EC values of both study locations were low and non-saline according to (Soil Survey Staff, 1994).

\subsection{Exchangeable Cations}

Exchangeable cations results are shown in (Table, 1), the values of exchangeable calcium are ranged between (5.8 -16.6 $\left.\mathrm{Cmol}_{\mathrm{c}} . \mathrm{kg}^{-1}\right)$ in Zawita location, while ranged between (8.8 -18.8

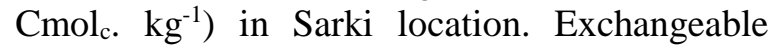
calcium have the highest values compared with the other exchangeable cations $\left(\mathrm{Mg}^{+2}, \mathrm{Na}^{+1}, \mathrm{~K}^{+1}\right)$ in both study locations this may be due to soils in both study locations are derived from calcareous parent material (Calcite and dolomite minerals) and release of calcium as a result of weathering process. Exchangeable calcium increased at surface horizons and decreased towards downward of pedons in both study locations. Exchangeable magnesium values ranged between (1.2 -9.4 $\left.\mathrm{Cmol}_{\mathrm{c} .} \mathrm{kg}^{-1}\right)$ in Zawita, whereas in Sarki ranged between (3-10 $\mathrm{Cmol}_{\mathrm{c}}$. $\mathrm{kg}^{-1}$ ), in the same manner of calcium the distribution pathway of exchangeable magnesium was tend to decreasing towards downward of pedon and high amount of it was concentrated at surface horizon. In spite of magnesium concentration was less than calcium but study pedons contain considerable amount of it because of these soils are derived from dolomite minerals as indicated it previously.

Ordinarily exchangeable sodium and potassium have low values in all soil horizons for study pedons and in line with previous exchangeable cations whereby decreasing with depth towards bottom of pedons with exception the sodium in pedon (9). Exchangeable sodium and potassium were ranged between (0.2- 0.8 Cmol $\left._{c} . \quad \mathrm{kg}^{-1}\right)$ and (0.48 $\left.-2.49 \mathrm{Cmol}_{\mathrm{c}} . \quad \mathrm{kg}^{-1}\right)$ respectively at Zawita location whereas at Sarki location both sodium and potassium values were ranged between $\left(0.13-0.87 \mathrm{Cmol}_{\mathrm{c}} \cdot \mathrm{kg}^{-1}\right)$ and $\left(\begin{array}{llll}0.76 & -2.68 & \mathrm{Cmol}_{\mathrm{c}} . & \mathrm{kg}^{-1}\end{array}\right)$ respectively. Exchangeable sodium values were much less than other cations, because of the studied pedons considered as non-saline soils, this is due to desalinization process. Concurrently, exchangeable potassium values were low and decreased with increasing depth, so the surface horizons have higher exchangeable potassium as compare with deep soil horizons, and it was relate existing potassium minerals at surface soil. Commonly, all exchangeable cations were concentrated at the surface and subsurface horizons (A and $\mathrm{B}$ horizons) and lower concentration in deep horizons ( $\mathrm{C}$ horizon) as a result of increasing organic and mineral soil colloids that are adsorbed cations on its surface in turn increasing their concentration at surface and subsurface horizons. In spite of there are no significant differences between cations value in both study locations but at Sarki location (Oak forest) were relatively high values compare with Zawita location (Pine forest) and these differences may be due to the decomposition degree of Oak trees residues compare with Pine trees residues.

\subsection{Cation Exchange Capacity (CEC)}

Cation exchange capacity (CEC) is one of the most important properties of the soil because has a relation with soil fertility and productivity. Study soils have a high CEC values at surface horizon (A) then decrease to downward direction of pedon ( $\mathrm{B}$ and $\mathrm{C}$ horizon) this is belongs to high organic matter content and adsorption increase of cations on the surface. The highest CEC value was (47.74 $\mathrm{Cmol}_{\mathrm{c}} . \mathrm{Kg}^{-1}$ ) found in (A) horizon in pedon (8) under forest cover of Oak 
trees whereas the lowest value was (11.76 $\mathrm{Cmol}_{\mathrm{c}} . \mathrm{Kg}^{-1}$ ) found in (C) horizon in pedon (4) under forest cover of Pine trees (Table, 1). Generally vertical distribution pathway of CEC in all study pedons showed the decreasing with depths (Exceptionally in pedon (6) under Oak trees at Sarki location) as a result of decrease organic material with depths that is consider the most important component in increasing the soil CEC and its playing a major role together with type and quantity of clay minerals in this process because of both of them have high specific surface area and have a high ability for adsorption cations on it surfaces. Evidently, CEC value was increased in deep soil horizon (C) in pedon (6) and this is attributed to distribution of quantity and type of clay as well as existing small amount of calcium carbonates particularly that was associated with clay particles in this horizon (Figure, 2) and (Table, 1 and 2).

Commonly, CEC values at Zawita location under Pine forest cover were relatively less than it at Sarki location under Oak forest cover, this is due to the effect of calcium carbonates particularly that are associate with colloid particles that caused coating particles and decrease specific surface area in turn relatively decrease the soil CEC under pine trees in comparison to soils under Oak trees, as well as the decomposition degree of Oak residues are more than it of Pine residues, because of pine leaves have a needle shape and more resistance for decomposition while Oak have petition leaves and easily decomposition, in addition to the soil $\mathrm{pH}$ effect particularly under Pine trees (Table, 1 and 2). On the other hand the values of CEC, symmetrical with values for the exchangeable cations because of buffering cation exchange capacity equal to summation of all cations in the soil. These results are agreed with the results obtained by Ozsoy and Aksoy, (2012) who found that the high CEC value can be attributed to high clay and organic matter contents. Eventually, can conclude the CEC of the soil under Oak trees was higher than it in soil under Pine trees and the high CEC value was found at surface horizons for all study pedons. The statistical analysis of results proved the inversely relationship and highly correlation between CEC and soil depth with exception pedon (6) because of these values decrease with depth. 

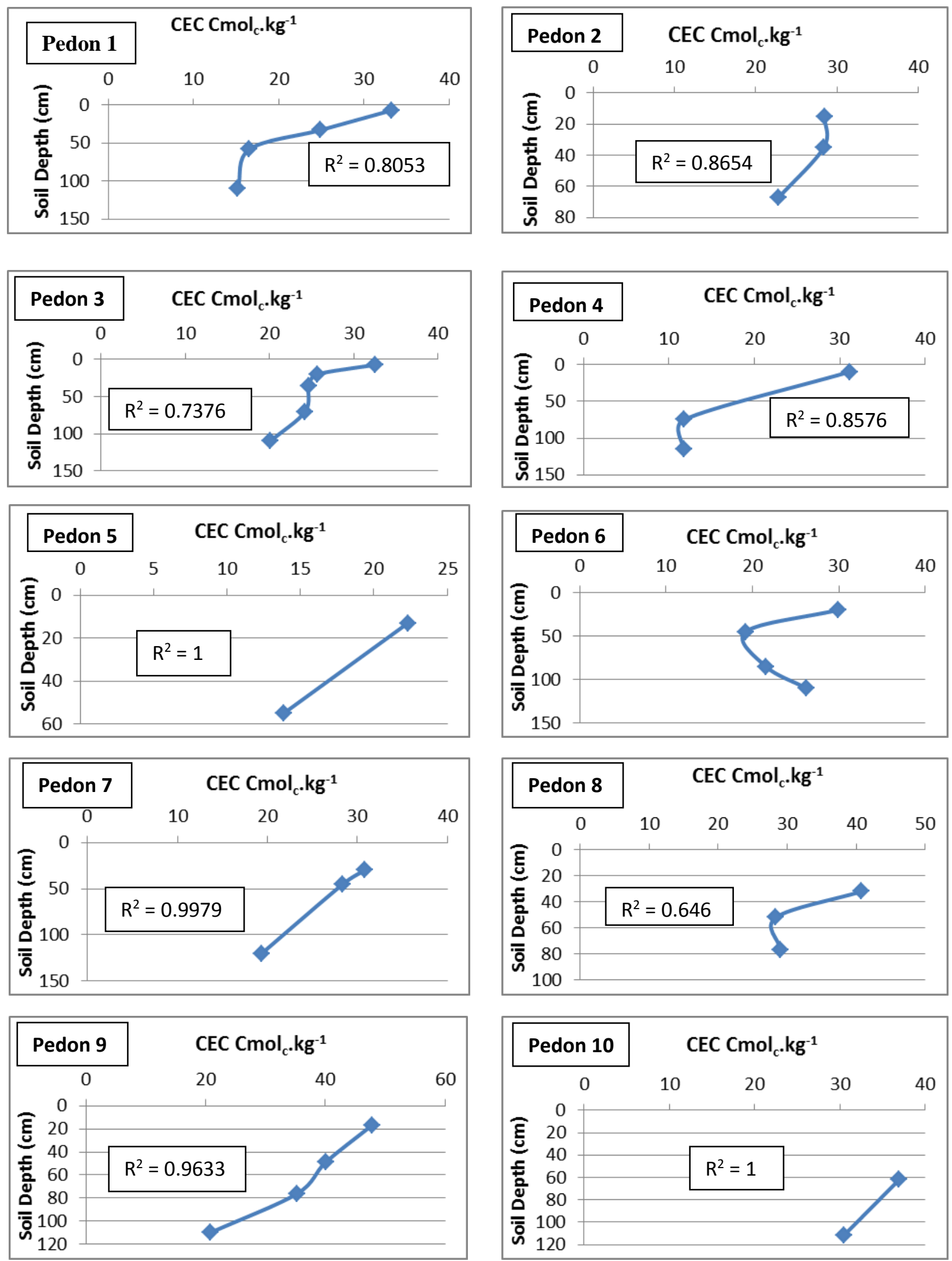

Fig. (2): Vertical Distribution of Cation Exchange Capacity in Study Pedons 
Table (1): Some Chemical Properties of Studied pedons

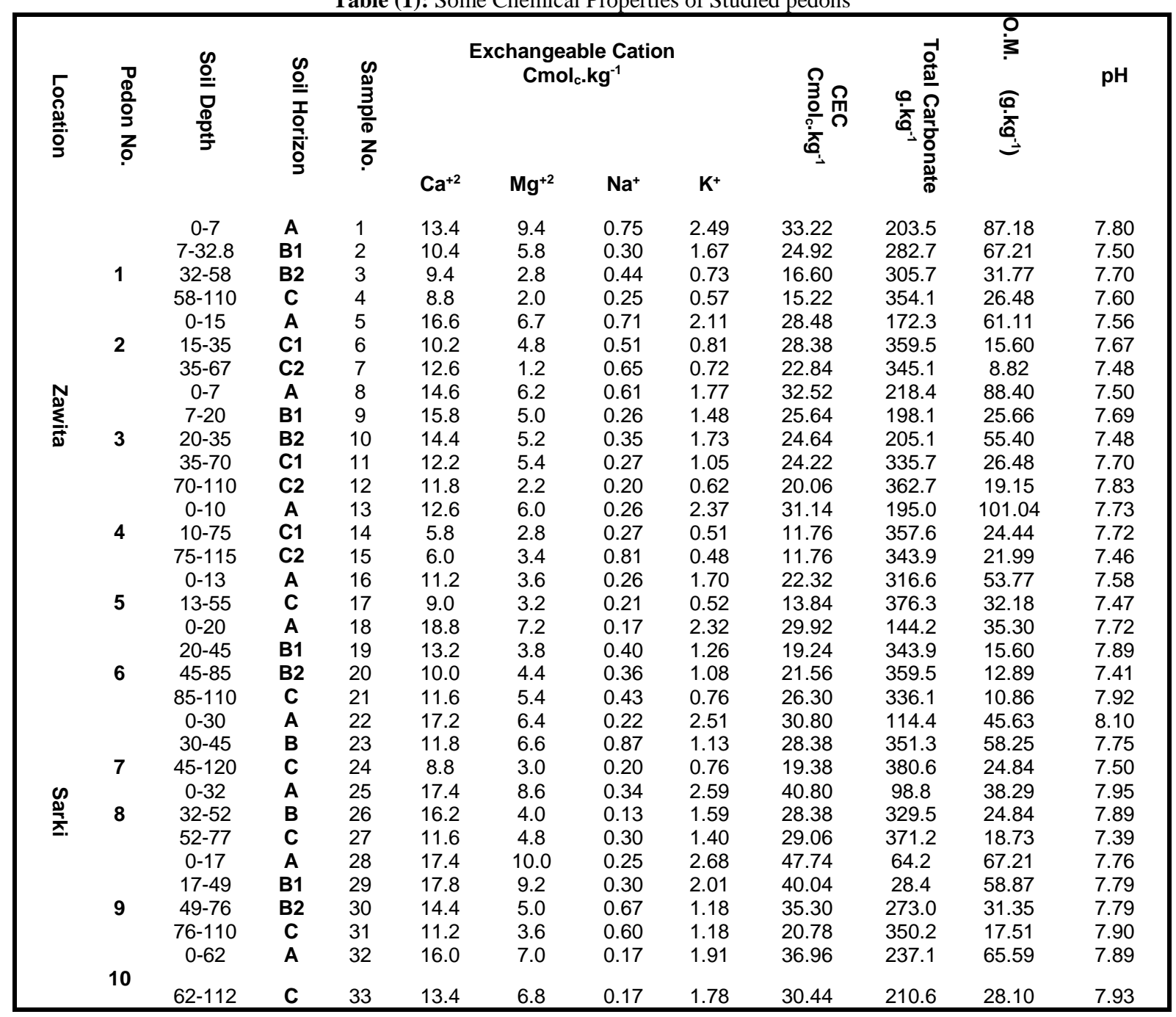

\subsection{Total Carbonate}

Total carbonates at Zawita location under pine forest cover were ranged between (172.3 376.3 g.kg $\left.{ }^{-1}\right) \quad$ whereas at Sarki location under Oak forest cover were ranged between (28.4380.6 g. $\mathrm{kg}^{-1}$ ) (Table, 1). The study soils characterized by high calcium carbonate content under both forest covers, because of are derived from limestone parent materials. The lowest value of Calcium carbonate was found in (B1) horizon in pedon (9) at Sarki location and this may be due to the effect of micro- topography (lower land) and leaching process (Eluviation) at this pedon position, additionally this pedon was development and caused movement of calcium carbonates from this horizon to the lower horizons (B2, and $\mathrm{C}$ ). On the other hand the vertical distribution of calcium carbonates in all study pedons under both forest covers indicated to increase total carbonate content towards downward of pedon from upper horizon to the lower horizons and this is belong to increasing rainfall effect and weathering of parent rocks (limestone) as a result of wetting and drying in addition to gains and losses processes, with exception pedon (10) that is contain calcium carbonate in (A) surface horizon more than it in (C) horizon (Figure, 3), this may be relate the calcium carbonates that are translocate from other positions as a result of erosion process, and deposition on the surface horizon of this pedon and in turn causes increase it, these results agreed with the similar results of Treadwell and McFadden (2000). In spite of calcium carbonates under pine trees cover has similar content of it under oak trees cover but has relatively high value under pine trees as a result of increase weathering process at Zawita location (Pine trees) more than it at Sarki location (Oak trees) this attributed to variation in topography and amount of rainfall in both study locations. Eventually can be concluded the 
study soils consider as calcareous soils and accumulation of calcium carbonate occurs as a result of pedogenic processes that are included calcification, leaching, enrichment, and illuviation and eluviation process. According to the statistical analysis there is highly correlation between total carbonates and soil depth exceptionally pedon (10), this means there is a directly proportional between total carbonate and soil
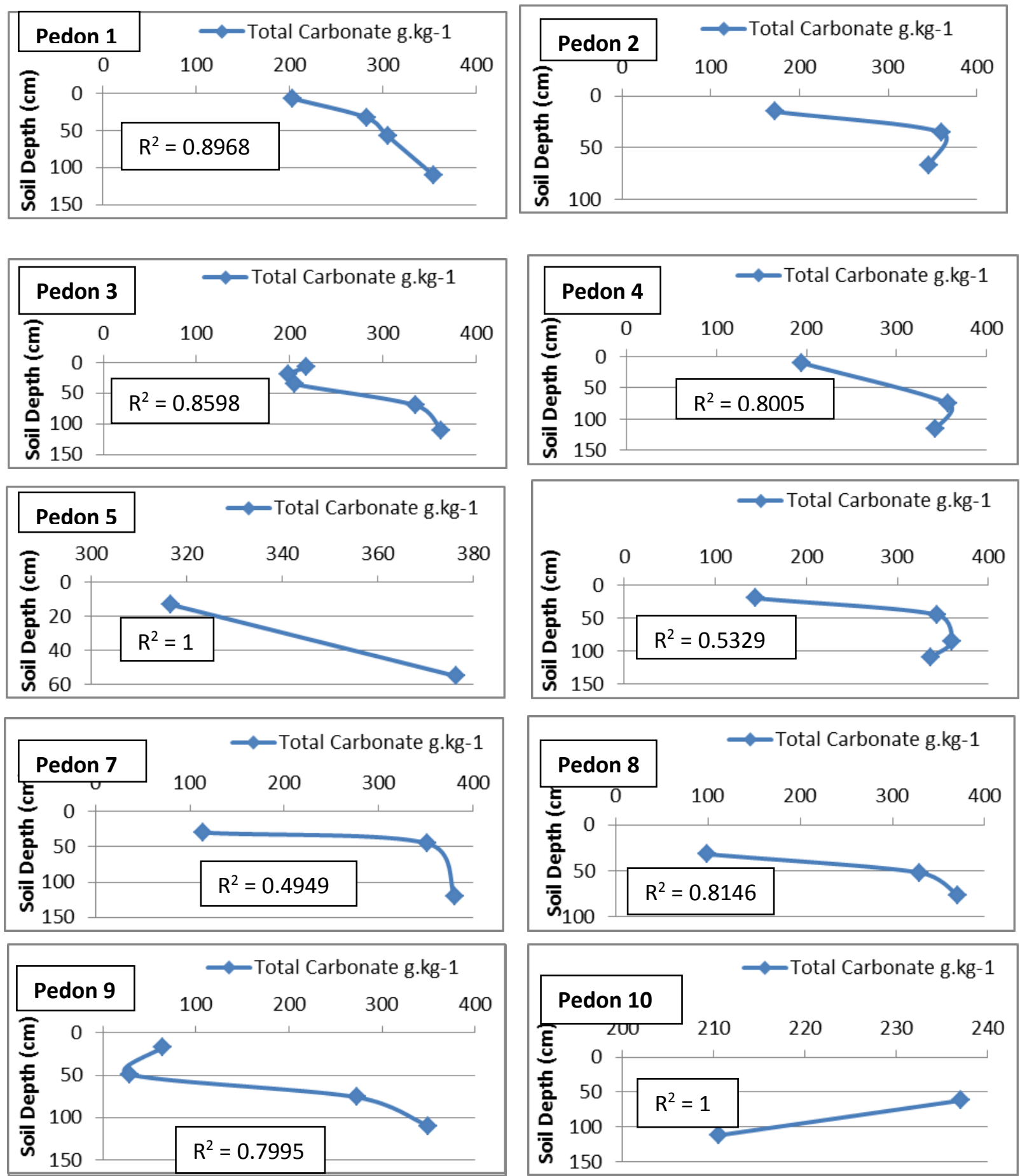

Fig. (3): Vertical distribution of Total Carbonates in Study Pedons 


\subsection{Organic Matter}

Organic matter content under pine trees cover at Zawita location was ranged between (8.82$\left.101.04 \mathrm{~g} . \mathrm{Kg}^{-1}\right)$, whereas under oak trees cover at Sarki location ranged between (10.8667.21g. $\left.\mathrm{Kg}^{-1}\right)$ (Table, 1$)$. Presumably the organic matter content under oak forest cover should be lower than it under pine forest cover, because of decomposition degree of oak residues more than it for pine residues and this is attributed to oak has broad leaves that have large surface area while pine has needle leaves but the results showed inverting this hypothesis as a result the density of oak trees at Sarki location was much less than density of pine trees at Zawita location consequently, organic matter content under pine forest cover was relatively higher value in comparison to organic matter content under oak forest cover. Generally, organic matter content in study pedons at both study locations under pine and oak forest covers was directly decreased towards depth of soil pedon with exception pedon (3) and (7). High organic matter content at surface horizon (A) in all study pedons belongs to increase the litter of trees and accumulation it on the soil surface and increase the organisms activity in active bio- depth of the soil pedon $(0-30) \mathrm{cm}$, (Bio- horizon) under optimum soil temperature and moisture regime, at the same time the plant roots contribute in increasing organic matter content in roots zone in the soil when die the plants. Accordingly, both littering and humification pedogenic processes are dominant at surface soil horizons in line with this, mollic epipedon was dominant on the surface of all study pedons, these results agreed with similar results that are proved by Ohno et al., (2007).

On the other hand organic matter decrease with depth in study pedons in subsurface and deep horizons as a result of decrease the organism's activity in addition to decrease, the plant and animal residues with depth (Table, 1). In pedon (3) organic matter content vibrated between increasing and decreasing this may be attributed to exist wooden roots in soil subsurface horizons in this pedon that are contribute in increase soil organic matter and in turn caused fluctuation in organic matter content in this pedon. Organic matter content in subsurface horizon (B) was more than it in surface horizon(A) in pedon (7), in spite of this difference between soil horizons was not significant nonetheless may be belongs to the soil erosion and removal soil surface furthermore, existing roots in subsurface horizon as another reason for increasing soil organic matter in this horizon (B), Implications emphasized the study soils contain passive and active organic matter that are represent humus and litter respectively, active soil organic matter, play a major role in soil health through important properties as soil colloids and responsible for many chemical, physical, biological, and morphological properties, such as adsorbed cations on its surface, soil reaction, providing energy for soil organisms, aggregation, soil structure, soil consistency, soil color, can be concluded from the results of study soils in both locations consider relatively healthy soils depending on the organic matter content.

\subsection{Particles Size Distribution and Soil Texture}

Soil texture is the relative distribution of sand, silt, and clay particles. The study results explained, clay particles were concentrated at surface and subsurface horizons (A and B) and the highest value was found in (B2) horizon in pedon (3) at zawita location (661 g. $\left.\mathrm{Kg}^{-1}\right)$, whereas the highest clay value was found in surface horizon (A) in pedon (10) and (8) which equal $\left(737 \mathrm{~g} . \mathrm{Kg}^{-1}\right)$ and $\left(730 \mathrm{~g} . \mathrm{Kg}^{-1}\right)$ respectively at sarki location this is may be due to, increase weathering intensity and in situ clay formation at soil surface whilst at subsurface horizon belongs to illuviation pedogenic process as a result of, relatively clay leaching from surface to subsurface horizon by rainfall. The lessivage process was occurs in pedon $(1,2$, and 9) as a result of mechanical migration of clay particles from $\mathrm{A}$ to $\mathrm{B}$ horizon and producing in $\mathrm{B}$ horizons relative enrichment in clay in turn formation Argillic diagnostic horizon. The clay content under oak trees cover was more than it under pine trees cover; this is implies that the observed variations in clay contents at both study locations have not been caused by tree species and must be attributed to the variation in weathering intensity and topographic nature in each location (Table, 2).

The values of silt content for the studied soils at Zawita ranged between (206.5 -394 g. $\mathrm{kg}^{-1}$ ), while ranged between (180.5 -463 g. $\left.\mathrm{kg}^{-1}\right)$ for soils at Sarki location. The results showed vibrating of silt particles between increase and decrease in all studied pedons with exception pedon 6 whereby decreased towards down of pedon, and in pedon 7 whereby increased towards down of pedon, and this was attributed 
to the effect of topography and pedon position in addition to the micro- climate. Generally in most studying pedons have high silt content at surface horizons in comparison to subsurface and deep horizons, this may be caused by Aeolian deposits. The sand fraction in soils under pine trees ranged between (128- 438 g. $\mathrm{kg}^{-1}$ ) but under oak trees ranged between (52.5- 390.5 $\left.\mathrm{g} \cdot \mathrm{kg}^{-1}\right)$, the results emphasized the sand fraction in soils, fluctuation between increase and decrease in un- arrangement pattern under pine trees at Zawita location, whilst was increased directly with depth under oak trees at Sarki location. Conspicuously sand fraction was more content under pine trees than it under oak trees oppositely for clay fraction distribution pattern.

Depending on the particles size distribution of study soils under pine trees indicated to the studying soils were clay, clay loam, and loam texture. Conversely, soil texture under oak trees was clay in all studying pedons with exception (B2) horizon in pedon (2) and (C) horizon in pedon (7). Explicitly, and according to the soil texture can be concluded the studying soils were more develop under oak forest cover in comparison to the soil under pine forest cover, because of the soil was finer in texture under oak trees more than the soil texture under pine trees. On the other hand the spatial variability in soil texture is related with the type, hardness, porosity and mineralogy of parent material additionally the weathering degree has a major role in specifying type of soil texture and cannot be explained by the effect of tree species directly but may be indirect effect for the trees species on the soil texture through its root system. Finally not just clay fraction is important in forest soil but sand and silt also have important role because of consider supporting stand for the trees.

Table (2): Some Physical Properties of Studied pedons

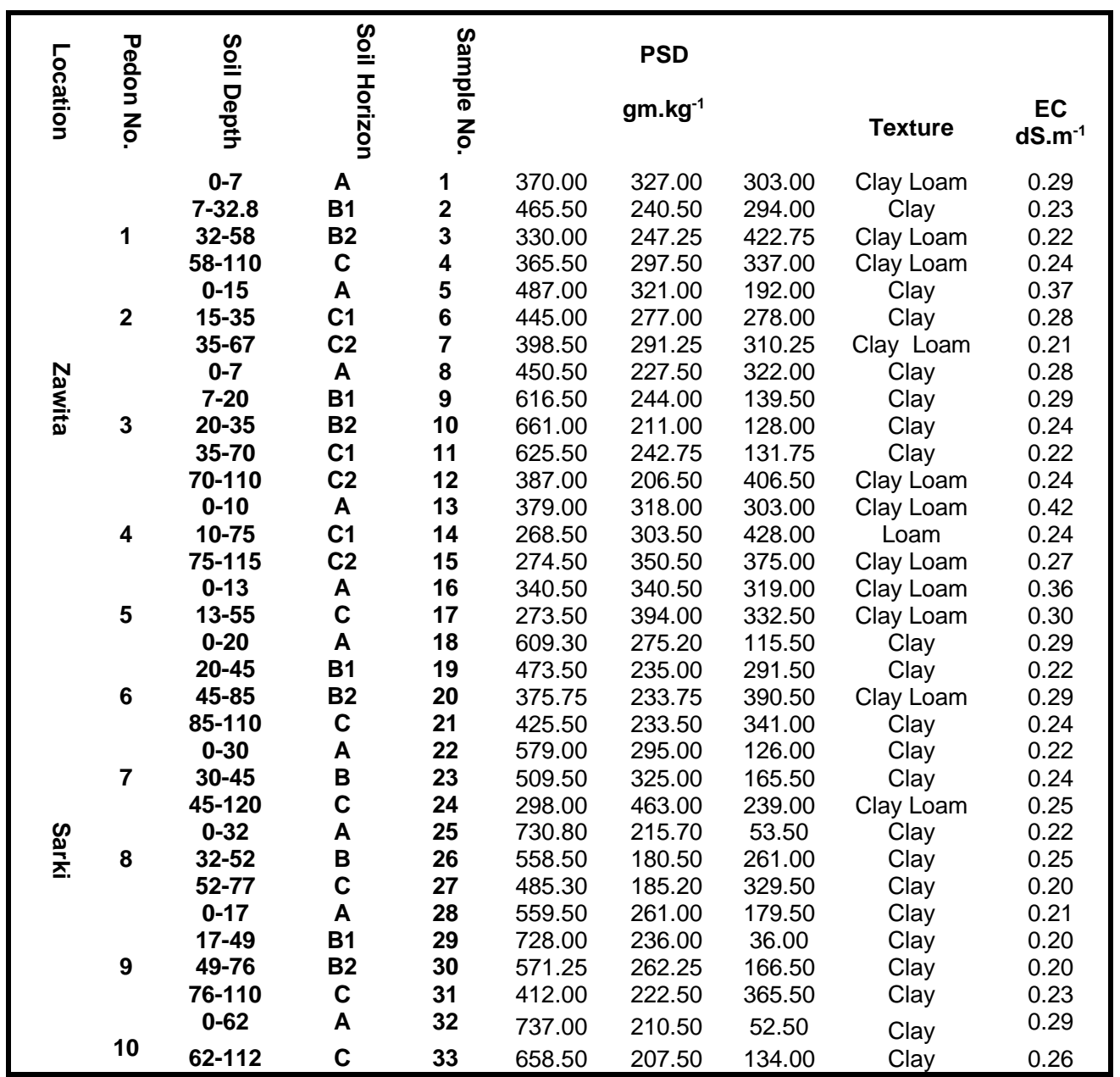




\section{CONCLUSIONS}

Can be concluded the study soils were slightly alkaline and there are not significant differences in $\mathrm{pH}$ values between two study locations under pine and oak trees. Non-saline soils and attributed to desalinization process. All exchangeable cations were concentrated at the surface and subsurface horizons (A and $\mathrm{B}$ horizons) and lower concentration in deep horizons (C horizon) additionally, at Sarki location under oak trees were relatively high values compare with Zawita location under pine trees. In general vertical distribution pathway of CEC in all study pedons showed the decreasing with depths. Commonly, CEC values at Zawita location under Pine forest cover were relatively less than it at Sarki location under Oak forest cover. Soluble cations were distributed randomly and vibrated between increase and decrease in different soil horizons for the study pedons at both locations. Calcium carbonates under pine trees cover have relatively high content as a result of increase weathering process at Zawita location (Pine trees) more than it at Sarki location (Oak trees). The study soils consider as calcareous and accumulation of calcium carbonate occurs as a result of pedogenic processes that are included calcification, leaching, enrichment, and illuviation and eluviation process. Littering and humification pedogenic processes are dominant at surface soil horizons in line with this; mollic epipedon was dominant on the surface of all study pedons. According to the soil texture can be concluded the studying soils were more develop under oak forest cover in comparison to the soil under pine forest cover, because of the soil was finer in texture under oak trees more than the soil texture under pine trees.

\section{REFERENCES}

Adel Rukia, Yaser Hammad, and Afraa Mayhoub. 2014. Pedological and microbiological study of a Pine forest soil profiles in the coastal Region (Mehwarti Forest). Tishreen University Journal for Research and Scientific Studies -Biological Sciences Series Vol. (36) No. (4). P 157.
Am-Euras. J. 2016. Toxicol. Sci., 8 (2): 60-68, 2016.

Boyle. J.R. 2005. in Encyclopedia of Soils in the Environment,

Estefan, G. S. Rolf, and R. John. 2013. Methods of Soil, Plant, and Water Analysis: A manual for the West Asia and North Africa region. 3rd Edition. ICARDA (International Center for Agricultural Research in the Dry Areas) Box 114/5055. Beirut, Lebanon, p. $116-118$.

Hesse, P. R. 1972. A text book of soil chemical analysis. Chemical publishing Co., Ins. New York.

Jiang L., Geng Z., Li S., She D., He X., Zhang Q., Liang C., Liu X., Jing W., Wang S. 2012. Soil cation exchange capacity and exchangeable base cation content in the profiles of four typical soils in the Xi-Shui Forest Zone of the Qilian Mountains. Acta Ecologica Sinica 32(11): 3368-3377. http://dx.doi.org/10.5846/stxb201104280563.

Klute, A, (Ed). 1986. Method of Soil Analysis. Part 1: Physical and Mineralogical Methods, 2 ${ }^{\text {nd }}$ Edition. Agron. Monogr. 9, Madison WI.

Loeppert, R. H. and D. L. Suarez .1996. Method of soil analysis part 3. Chemical methods. Soil Sci. Soc. Am. And Am. Soc. Agron., 677, S. Segoe Ed., Madison Wisconsin 53711, USA, SSSA. Book Series No. 5.

Mahjoory, R. A. 1975. Clay mineralogy, physical and chemical properties of some soils in arid regions of Iran. Soil Sci. Soc. Am. Proc. $32: 1157-1164$

Marlow J., Peart J. R. 2014. Experimental reversal of soil acidification in a deciduous forest: implications for seedling performance and changes in dominance of shade-tolerant species. Forest Ecology \& Management 313: 63-68.

http://dx.doi.org/10.1016/j.foreco.2013.10.036

Negash L., Kagnew B. 2013. Mechanisms for the successful biological restoration of the threatened African pencil cedar (Juniperus procera Hochst. ex. Endl., Cupressaceae) in a degraded landscape. Forest Ecology \& Management 310: 476-482. http://dx.doi.org/10.1016/j.foreco.2013.08.050 
Nelofer Jamil, Naheed Sajjad, Humaira Ashraf, Zubia Masood, Zahoor Ahmed Bazai, Rukhsana Khan, Nida Anjum, Farah Akmal, Nazia Arbab, Palwasha Tareen and Rabail Khan.2016. Physical and Chemical Properties of Soil Quality Indicating Forests Productivity: A Review American-Eurasian Journal of Toxicological Sciences 8 (2): 6068.

O’Neill, Katherine P.; Amacher, C. Michael; Perry, H. Charles. 2005. Soils as an indicator of forest health: a guide to the collection, analysis, and interpretation ofsoil indicator data in the Forest Inventory and Analysis program. Gen. Tech. Rep. NC-258. St. Paul, MN: U.S. Department of Agriculture, Forest Service, North Central Research Station. 53 p.

Ohno S., K. Kawai, and S. Tachibana. 2007. Elastoplastic constitutive model for unsaturated Soils applied effective degree of saturation as a parameter expressing stiffness. J. JSCE 63 (4): 1132- 114.

Ozsoy, G. and E. Aksoy 2012. Genesis and Classification of some Mollisols Developed under Forest Vegetation in Bursa, Turkey. Int. J. Agric. Biol. 14(1):75-80.

Page, A.L., R.H. Miller, and D.R.Kenney.1982. Methods of soil Analysis part (2) $2^{\text {nd }}$ ed. Agronomy 9 Am. Soc. Agron. Madison, Wisconsin.

Pal D.K., S.P. Wani, K.L. Sahrawat. 2012. The original Kasireddipalli soils (Sodic Haplusterts) now qualify as Typic Haplusterts. Vertisols of tropical Indian environments: Pedology and edaphology. Geoderma 189-190 P46.

Polemio, M. J. and J. D. Rhoads.1977. Determination cation exchange capacity a new procedure for calcareous and gypsiferous soils. Soil Soc.Am.Proc. 18:365-368.

Prasad KG Singh SB Gupta GN and George M. 1985. Studies on changes in soil properties under different vegetation. Indian For 111: 794-801

Robert "Bobby" Grisso, Mark Alley, W.G., David Holshouser, Wade Thomason. 2009. Precision Farming Tools:Soil Electrical Conductivity,
Virginia Polytechnic Institute and State University, P1-6.

Rowell, D. L. 1996. Soil science methods and application. Welsy, Longman, London.

Sharma J.C. and Yogender Sharma. 2004. Effect of FOREST ECOSYSTEMS ON SOIL PROPERTIES - A REVIEW, Department of Soil Science and Water Management, Dr Y. S. Parmar University of Horticulture and Forestry, Nauni-Solan - 173230, India. Agric. Rev., 25(1): P 17.

Šnajdr J, V. Valášková, V. Merhautová, J. Herinková, T. Cajthaml, P. Baldrian. 2008. Spatial variability of enzyme activities and microbial biomass in the upper layers of Quercus petraea forest soil. Soil Biol Biochem. 40: 2068-2075. [Google Scholar].

Soil Survey Staff. 1994. Key to soil taxonomy. Pocahontas press, Blackburg. VA.

Soil Survey Staff. 2006. Keys to soil taxonomy tenth edition, United States, Department of Agriculture natural resources conservation service. Sw. Washington DC.

Treadwell, S.C. and L.D. McFadden. 2000. Influence of parent material and grain size on carbonate coatings in gravely soils, Palo Duro Wash, New Mexico. Geoderma, 94: 1-22.

Unanaonwi, Okpo Esio, \& Chinevu, Christian Nnaemeka. 2013. Physical and Chemical Characteristics of Forest Soil in Southern Guinea Savanna of Nigeria. Global Journal of Science Frontier Research Agriculture and Veterinary Volume 13 Issue 10 Version 1.0 Year 2013 Type: Double Blind Peer Reviewed International Research Journal Publisher: Global Journals Inc. (USA) Online ISSN: 2249-4626 \& Print ISSN: 0975-5896.

Walkley, .A. and I. Black. 1965. Determination of organic matter. In:C. A. Black. Method of soil analysis. Part 2. Agronomy No. 9. Am. Soc. Of Agron.,Inc. Madison, Wisconsin, P. 13731376.

Yahia, A. M. 1982. Genesis and classification of Zawita forest soil in Dohuk province. Msc thesis. College of agriculture and forestry, Mosul University Iraq. 
خواندنا هندهى ساخلهتيّن فيزيكى و كيميكى يِين ناخيّن دارستانَّ د بن دوو جوريّن دارا يِين جياواز

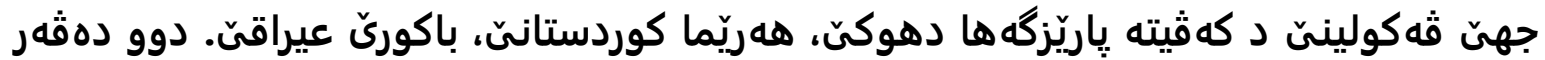

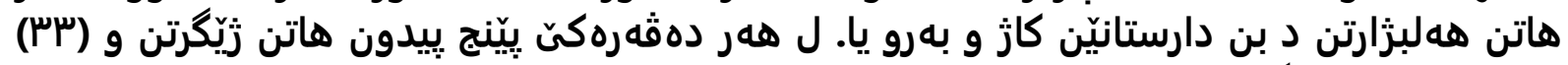

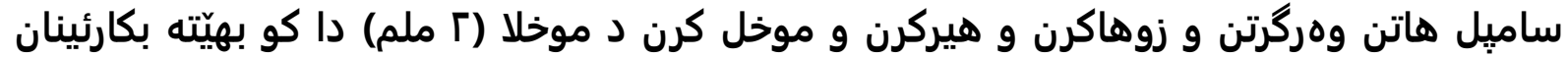

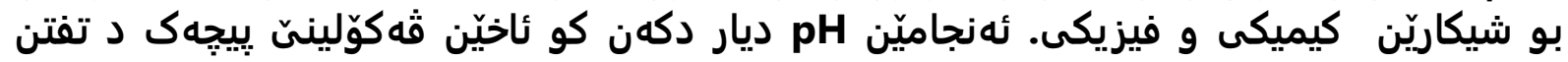

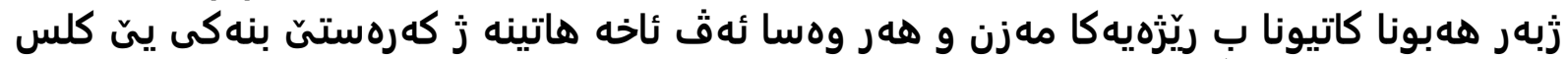

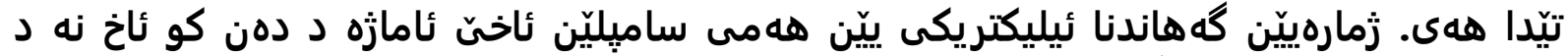

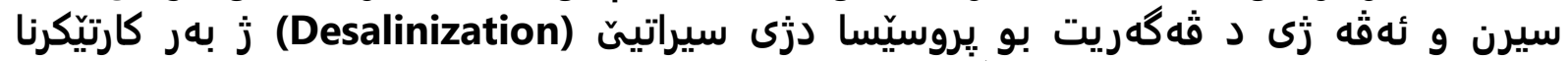

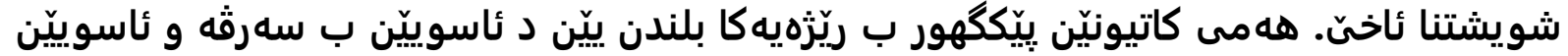

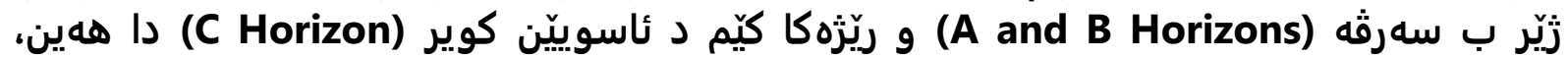

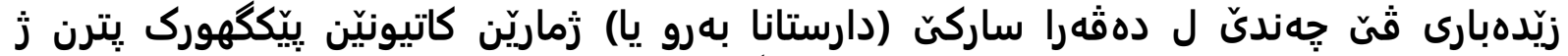

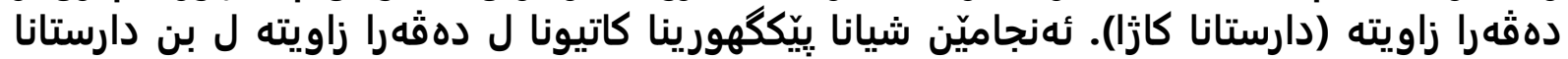

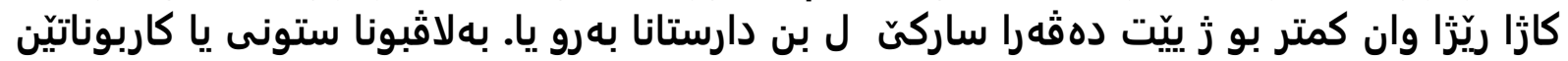

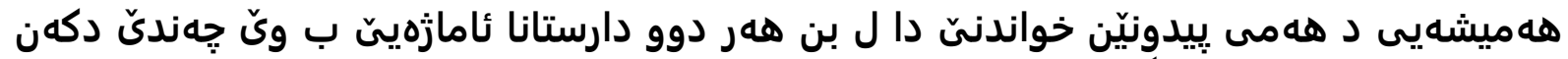

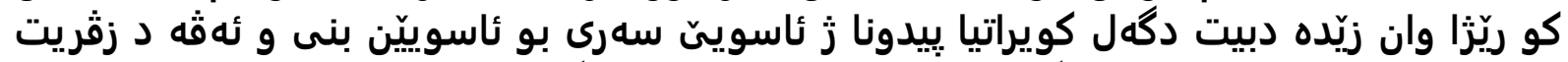

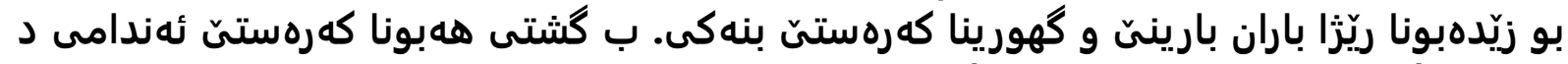

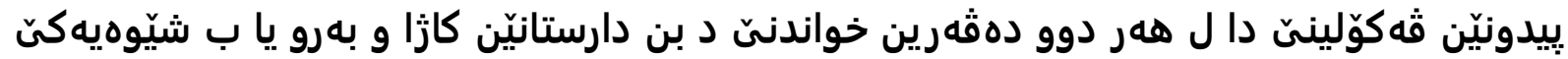

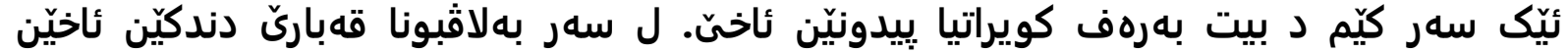

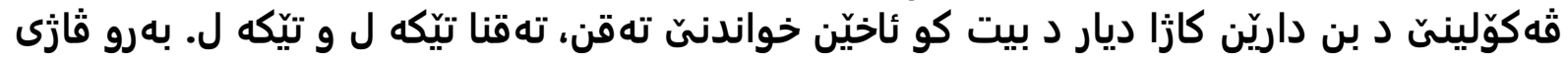

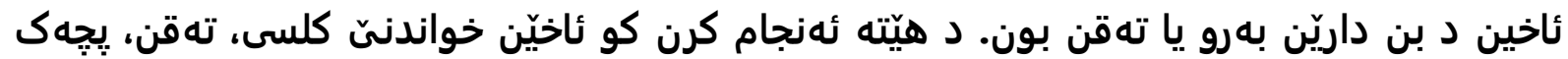

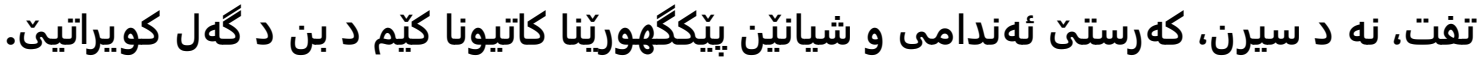

دراسة بعض الصفات الفيزيائية و الكيميائية لترب الغابات تحت نوعين مختلفين من الأشجار

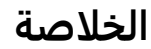
تقع منطقة الدراسة في محافظة دهوك ، إقليم كردستان ، شمال العراق. تم اختيار موقعين

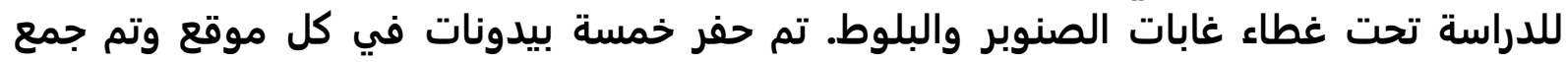




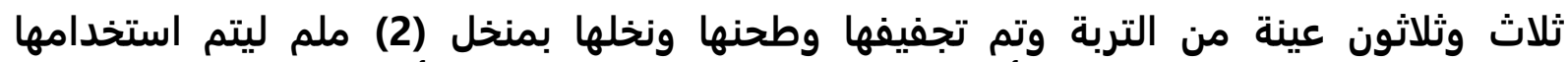

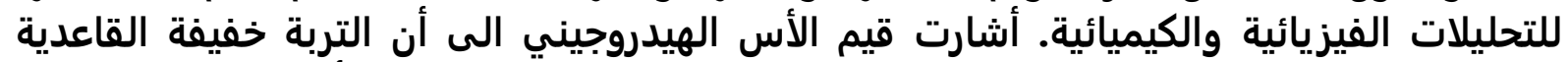

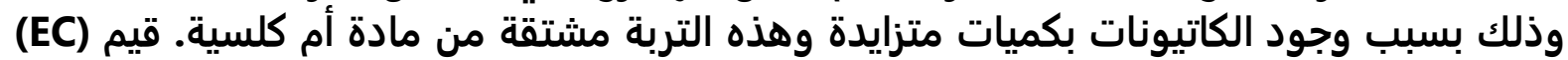

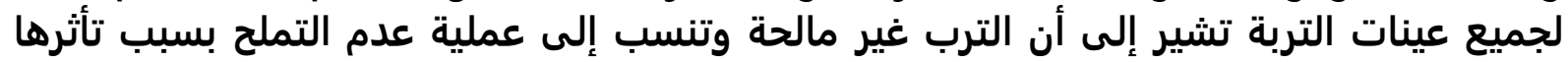

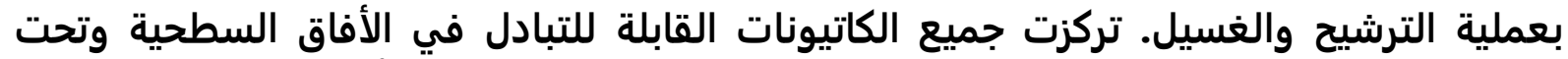

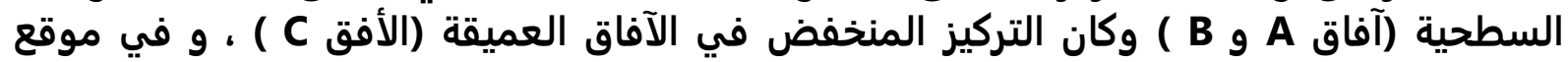

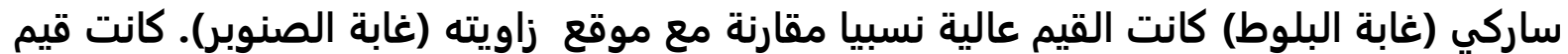

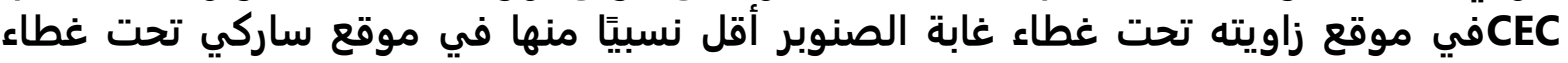

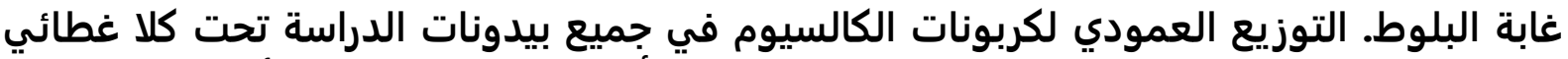

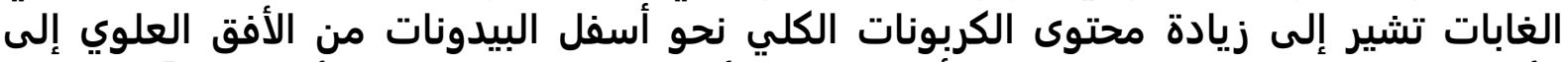

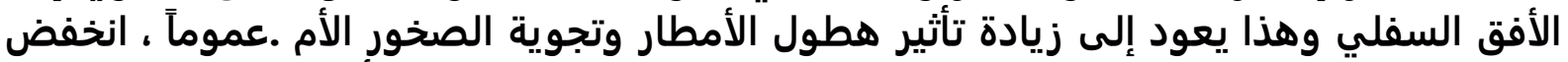

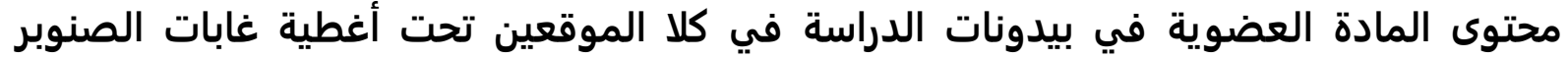

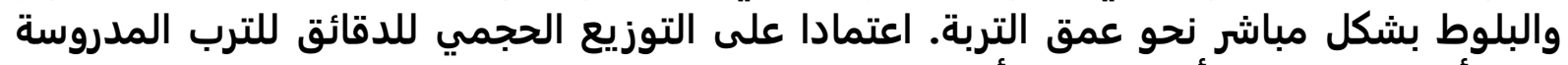

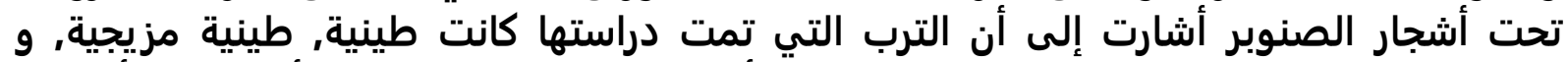

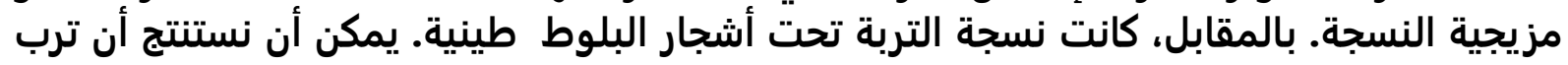

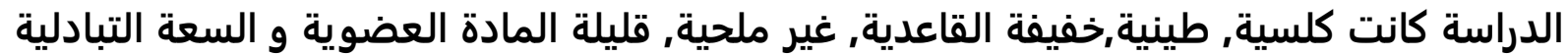

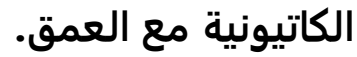

